\title{
Declining incidence of AIDS dementia complex after introduction of zidovudine treatment
}

Peter Portegies, Jan de Gans, Joep M A Lange, Mayke M A Derix, Hans Speelman, Margreet Bakker, Sven A Danner, Jaap Goudsmit

\section{Abstract}

Objective-To assess the incidence of the AIDS dementia complex and the presence of HIV I p24 antigen in cerebrospinal fluid in relation to zidovudine treatment.

Design-Retrospective study of a consecutive series of patients with AIDS from 1982 to 1988.

Setting-An academic centre for AIDS.

Patients-196 Patients with AIDS and neurological symptoms examined from 1982 to 1988.

Interventions-Zidovudine treatment, which was introduced to The Netherlands on 1 May 1987 for patients with severe symptoms of HIV infection (Centers for Disease Control groups IVA, B, C, and D).

Main outcome measures-Diagnosis of AIDS dementia complex and presence of HIV I p24 antigen in eerebrospinal fluid.

Results-The AIDS dementia complex was diagnosed in 40 of the $196(20 \%)$ patients with AIDS. Thirty eight of 107 patients with AIDS (36\%) not taking zidovudine developed the AIDS dementia complex compared with two of the $89(2 \%)$ taking the drug $(p<0.00001)$. The incidence of the AIDS dementia complex increased to $53 \%$ in the first half of 1987, after the introduction of zidovudine in May 1987 , decreasing to $10 \%$ in the second half of 1987 and to $3 \%$ in 1988 . Dementia was diagnosed before definition of the AIDS dementia complex (1986) according to DSM-III criteria and there was good agreement between diagnosis before and after 1986 .

Sixteen of 61 samples of cerebrospinal fluid (26\%) from patients with AIDS (10 with the AIDS dementia complex) not taking zidovudine were positive for HIV I p24 antigen, whereas none of 37 cerebrospinal fluid samples from patients with AIDS (two with the AIDS dementia complex) taking zidovudine were positive.

Conclusions-The incidence of AIDS dementia complex in patients with AIDS declined after the introduction of systematic treatment with zidovudine; the AIDS dementia complex might be prevented by inhibiting viral replication in the central nervous system.

\section{Introduction}

In patients with AIDS the nervous system is commonly affected.' : One of the most common neurological syndromes is the AIDS dementia complex, characterised by abnormalities in cognition, motor performance, and behaviour, "which is directly related to infection of the brain with HIV I and usually becomes clinically overt in the advanced stages of the infection. ${ }^{+}$The epidemiology and course of the AIDS dementia complex have not yet been precisely defined. Without treatment between a third and two thirds of all patients with AIDS eventually develop a mild or severe form of the AIDS dementia complex. ${ }^{2-1}$ With oral administration of zidovudine appreciable concentrations of the drug can be attained in cerebrospinal fluid, "and some beneficial effects of zidovudine treatment in patients with the AIDS dementia complex have been described..$^{y-11}$

Detection of HIV I p24 antigen in the cerebrospinal fluid, the presence of which is independent of HIV I p24 antigen concentration in the serum, reflects intrathecal expression of HIV $\mathrm{I}^{12-14}$ and is strongly correlated with the AIDS dementia complex in adults and progressive encephalopathy in children with AIDS..$^{134}$ In symptomless and neurologically normal adults infected with HIV I the p24 antigen is rarely detected in the cerebrospinal fluid. ${ }^{1+15}$ Zidovudine treatment is associated with decreasing HIV I p24 antigen concentrations in serum ${ }^{16}$ and cerebrospinal fluid. ${ }^{178}$

In this study we determined the incidence of the AIDS dementia complex from 1982 to 1988 in 196 patients with AIDS and neurological symptoms. The introduction of zidovudine treatment to The Netherlands (1 May 1987) was covered to assess a possible relation between the treatment and any observed change in the incidence of the AIDS dementia complex. The effect of zidovudine on the presence of HIV I p24 antigen in cerebrospinal fluid was studied in the patients receiving zidovudine treatment and those not receiving treatment.

\section{Patients and methods}

Between October 1982 and 31 December 1988 all 260 patients with symptomatic infection with HIV I and neurological symptoms who were seen at the AIDS unit of this centre were examined by a neurologist. They were divided into two groups: one comprised 111 patients seen before 1 May 1987, when zidovudine was introduced, and the other comprised 149 patients seen after its introduction. Systematic treatment with zidovudine was introduced for patients with severe symptoms of HIV I infection (Centers for Disease Control groups IVA, B, C, and D). We classified our patients according to the Centers for Disease Control classification of HIV I infection. ${ }^{14}$ In the first group 85 of the 111 patients $(77 \%)$ were classified as having AIDS (groups IV $\mathrm{Cl}$ and $\mathrm{D}$ as the AIDS diagnosis at presentation), and in the second group 111 of the 149 patients $(75 \%)$. The mean time between diagnosis of AIDS and neurological examination was not significantly different between the groups ( 3.1 months (median 0 months, range 0.29 months) in first group $v$ 3.5 months (median 1 month, range $0-24$ months) in the second).

Before the AIDS dementia complex was defined as a distinct clinical syndrome in $1986^{3}$ the diagnosis of dementia in these patients had been based on DSM-III 
(Diagnostic and Statistical Manual of Mental Disorders) criteria.$^{20}$ Motor abnormalities were present in all these demented patients, which agreed retrospectively with the diagnostic criteria of the AIDS dementia complex. Abnormalities in cognition, motor performance, or behaviour, or both, were present in the 40 patients classified as having the AIDS dementia complex between 1982 and 1988. The diagnostic criteria used during this period did not change substantially.

Computed tomography of the brain was performed in 39 of the 40 patients with the AIDS dementia complex, cerebrospinal fluid was examined in 24 , and a neuropsychological examination was performed in 16 .

Cerebrospinal fluid was tested for HIV I p24 antigen by a solid phase, sandwich type enzyme immunoassay (Abbott Laboratories, North Chicago, United States) as previously described." The cut off value indicating a positive result varied from 50 to $65 \mathrm{ng} / \mathrm{l}$ among assays.

\section{Results}

Of the 260 patients infected with HIV I who had neurological symptoms, $196(75 \%)$ were confirmed as having AIDS, and 40 of these $(20 \%)$ were classified as having the AIDS dementia complex. In $33(83 \%)$ of these patients this had been diagnosed before the introduction of zidovudine and in seven (18\%) thereafter (fig 1), comprising $39 \%$ and $6 \%$ respectively of the total numbers of patients with AIDS in the two groups $(\mathrm{p}<0 \cdot 00001)$.

The yearly number of new patients with neurological symptoms increased from one in 1982 to 66 in 1988 (fig 1). After the introduction of zidovudine the proportion of patients using the drug increased from $26 \%$ at the end of the first half of 1987 to $84 \%$ at the end of 1988 (fig 2). The incidence of the AIDS dementia complex increased from $21 \%$ in the second half of 1985 to $53 \%$ in the first half of 1987 , afterwards decreasing to $10 \%$ in the second half of 1987 and to $3 \%$ throughout 1988 (fig 2). Shortly after the introduction of zidovudine the proportion of patients with AIDS taking the drug increased to over $75 \%$ (fig 2). Of all patients who had never taken zidovudine (107), 33 of the $85(39 \%)$ examined before the drug was introduced had the AIDS dementia complex and five of $22(23 \%)$ examined afterwards had the syndrome $(p=0 \cdot 12258)$. Thus significantly more patients who were not taking zidovudine developed the AIDS dementia complex $(38 / 107,36 \%)$ compared with those who were $(2 / 89$, $23 \%)(\mathrm{p}<0.00001)$.

Though the incidence of the AIDS dementia complex declined, a proportionally larger number of cases of other neurological problems were seen (table I).

Cerebrospinal fluid collected from 98 patients with AIDS (24 with the AIDS dementia complex) during the study period and tested for HIV I p24 antigen

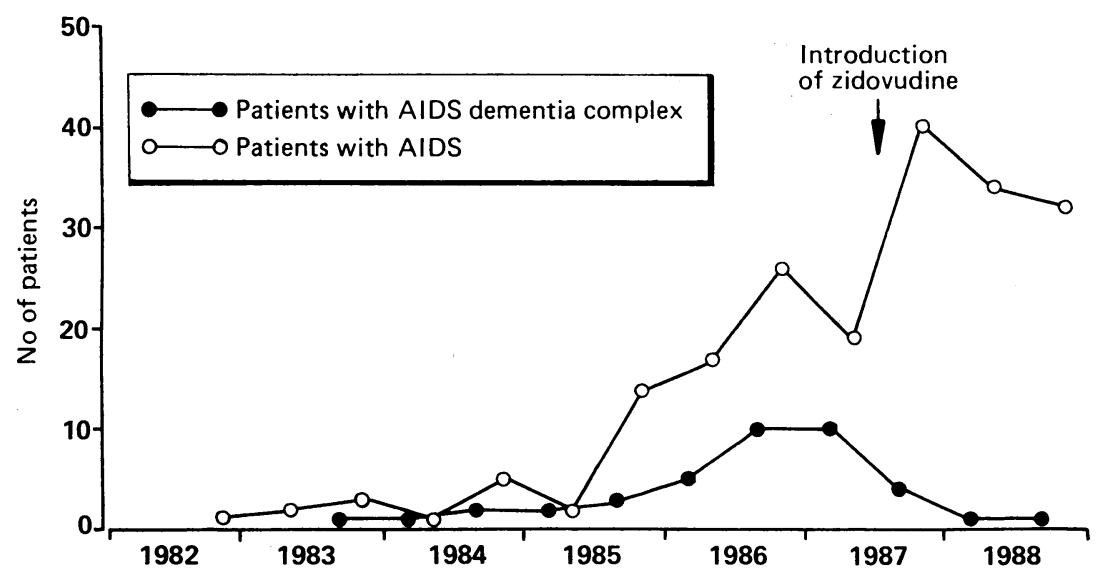

FIG 1-Half yearly numbers of patients with AIDS and patients with AIDS dementia complex, 1982-8

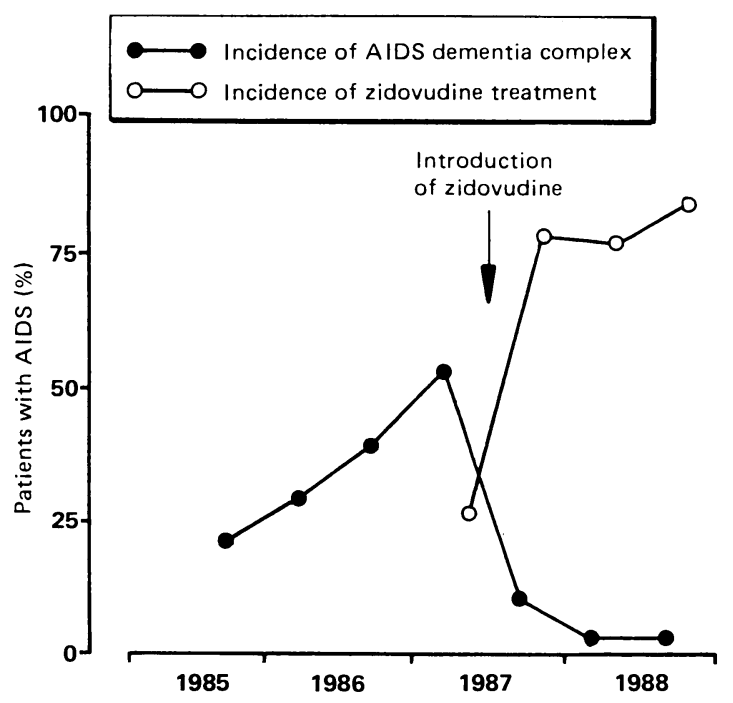

FIG 2-Half yearly incidence of AIDS dementia complex and percentage of patients with AIDS taking zidovudine, 1985-8. percentage of patients with AIDS taking zidovudine, $1985-8$.
(Percentage values omitted before mid-1985 due to low numbers of patients)

showed that, of 61 samples from patients not taking zidovudine at the time of lumbar puncture, 16 were positive for the antigen (10 patients with the AIDS dementia complex) and 45 were negative (12 patients with the AIDS dementia complex); all 37 samples from AIDS patients (two with the AIDS dementia complex) taking zidovudine were negative (table II; $\mathrm{p}=0 \cdot 00021$ ).

\section{Discussion}

In our patient population with AIDS a striking decline in the AIDS dementia complex was observed in those taking zidovudine after its introduction to The Netherlands. This result may have been biased to some extent as this was a retrospective study. Some patients in the terminal stages of AIDS may have developed the AIDS dementia complex without having been investigated for this condition; if cases had been missed this should not, however, necessarily favour the group taking zidovudine. Retrospectively, all cases of AIDS related dementia diagnosed before the AIDS dementia complex was defined as a distinct syndrome in 1986 met the clinical features of the syndrome, as described by Navia et al. ${ }^{3}$ Therefore, we conclude that the change in incidence of the AIDS dementia complex was not caused by a change in diagnostic criteria.

The declining incidence of the AIDS dementia complex was matched by a decline in the presence of HIV I p24 antigen in the cerebrospinal fluid with zidovudine treatment. As expression of this antigen in the cerebrospinal fluid has been correlated with the AIDS dementia complex ${ }^{1+}$ the causal relation between zidovudine treatment and the decline in the AIDS dementia complex is strengthened.

The benefits of zidovudine on systemic manifestations of AIDS and the AIDS related complex seem to be of limited duration." Even when zidovudine is started in the asymptomatic stage of HIV infection progression to pneumonia caused by Pneumocystis carinii may occur (J W Mulder et al, unpublished results). The effect of zidovudine on the development of the AIDS dementia complex thus seems to compare favourably with that on systemic manifestations. In systemic infection HIV I induces severe immunological abnormalities with eventual massive loss of $\mathrm{CD}^{+}$ lymphocytes. ${ }^{23}$ In brains of patients with the AIDS dementia complex cytolytic infection of neurons is limited ${ }^{24}$; almost exclusively cells of monocyte or macrophage lineage have been shown to contain viral genome and express viral proteins. ${ }^{625} 26$ This indicates that the AIDS dementia complex may result from 
TABLE I - Neurological diagnosis in 196 patients with AIDS, 1982-8. Figures are numbers (percentages) of patients

\begin{tabular}{|c|c|c|c|c|c|c|c|}
\hline Diagnosis* & $\begin{array}{c}1982 \\
(\mathbf{n}=1)\end{array}$ & $\begin{array}{c}1983 \\
(\mathrm{n}=5)\end{array}$ & $\begin{array}{l}1984 \\
(\mathrm{n}=6)\end{array}$ & $\begin{array}{c}1985 \\
(\mathrm{n}=16)\end{array}$ & $\begin{array}{c}1986 \\
(n=43)\end{array}$ & $\begin{array}{c}1987 \\
(\mathbf{n}=59)\end{array}$ & $\begin{array}{c}1988 \\
(\mathrm{n}=66)\end{array}$ \\
\hline AIDS dementia complex & 0 & 1 & 3 & $5(31)$ & $15(35)$ & $14(24)$ & $2(3)$ \\
\hline Asepti & & & & & $2(5)$ & $2(3)$ & $6(9)$ \\
\hline Peripheral neuropathy & & & & $5(31)$ & $22(51)$ & $11(19)$ & $14(21)$ \\
\hline Cerebral toxoplasmosis & & & 2 & $7(44)$ & $6(14)$ & $15(25)$ & $18(27)$ \\
\hline Crypt & 1 & & & $2(13)$ & $3(7)$ & $7(12)$ & $4(6)$ \\
\hline Cytomegalovirus polyradiculopathy & & & 1 & 16 & & $2(3)$ & $3(5)$ \\
\hline Progressive multifocal leucoencephalopathy & & 1 & & & $1(2)$ & $4(7)$ & $1(2)$ \\
\hline Limphoma & & & & 16 & & $1(2)$ & $2(3)$ \\
\hline Miscellaneous & & 3 & & $3(19)$ & $2(5)$ & $15(25)$ & $21(32)$ \\
\hline
\end{tabular}

^Multiple diagnoses in some patients.

TABLE II-Presence of HIV I p24 antigen in samples of cerebrospinal fluid according to zidovudine treatment

\begin{tabular}{lcc}
\hline & Negative samples & Positive samples \\
\hline Untreated patients & 45 & 16 \\
Treated patients & 37 & 0 \\
\hline Total & 82 & 16
\end{tabular}

secondary effects of HIV expression, possibly toxic in origin. . $^{2-29}$

Although HIV is present in the brain early in the course of the disease, ${ }^{12}$ reactivation of viral expression in the brain seems to be the essential step in the development of the AIDS dementia complex. The results of our study suggest that with antiviral treatment the AIDS dementia complex might be prevented by inhibiting the reactivation of viral replication.

We thank $\mathrm{H}$ van Crevel and J Stam for critical comments, and $\mathrm{E}$ van Dongen for preparing the manuscript.

\footnotetext{
1 Snider WD, Simpson DM, Nielsen S, et al. Neurological complications of acquired immune deficiency syndrome: analysis of 50 patients. Ann Neurol 1983;14:403-18.

2 McArthur JC. Neurologic manifestations of AIDS. Medicine 1987;66:407-37.

3 Navia BA, Jordan BD, Price RW. The AIDS dementia complex: I. Clinical features. Ann Neurol 1986;19:517-24.

4 Epstein LG, Sharer LR, Gajdusek DC. Hypothesis: AIDS encephalopathy is due to primary and persistent infection of the brain with a human retrovirus of the lentivirus subfamily. Med Hypotheses 1986;21:87-96.

5 Shaw GM, Harper ME, Hahn BH, et al. HTLV-III infection in brains of Shaw GM, Harper ME, Hahn BH, et al. HTL -III infection in brains
children and adults with AIDS encephalopathy. Science 1985;227:177-82.

6 Koenig S, Gendelman HE, Orenstein JM, et al. Detection of AIDS virus in macrophages in brain tissue from AIDS patients with encephalopathy. Science 1986:223:1089-93.

7 Price RW, Brew B, Sidtis J, et al. The brain in AIDS: central nervous system HIV-1 infection and AIDS dementia complex. Science 1988;239:586-92.
}

8 Yarchoan $\mathrm{R}$, Klecker $\mathrm{RW}$, Weinhold $\mathrm{KJ}$, et al. Administration of 3'-azido-3'deoxythymidine, an inhibitor of HTLV-III/LAV replication, patients with AIDS or AIDS-related complex. Lancet 1986; ;:575-80.

9 Yarchoan R, Berg G, Brouwers P, et al. Response of human immunodeficiencyvirus-associated neurological disease to $3^{\prime}$-azido-3'deoxythymidine. Lancet 1987;i:132-5.

10 Schmitt FA, Bigley JW, McKinnis R, et al. Neuropsychological outcome of zidovudine (AZT) treatment of patients with AIDS and AIDS-related complex. N Engl f Med 1988;319:1573-8.

11 Pizzo PA, Eddy J, Falloon J, et al. Effect of continuous intravenous infusion of zidovudine (AZT) in children with symptomatic HIV infection. $N$ Engl 7 of zidovudine 1988 ; $319.889-96$.

12 Goudsmit J, de Wolf F, Paul DA, et al. Expression of human immunodeficiency virus antigen (HIV-Ag) in serum and cerebrospinal fluid during deficiency virus antigen ( $\mathrm{HIV}-\mathrm{Ag}$ ) in serum and cereb
acute and chronic HIV infection. Lancet 1986;ii: 177-80.

13 Epstein LG, Goudsmit J, Paul DA, et al. HIV expression in the cerebrospinal fluid of children with progressive encephalopathy. Ann Neurol 1987;21 397-401.

14 Portegies P, Epstein LG, Tjong A, et al. Human immunodeficiency virus type 1 antigen in cerebrospinal fluid. Correlation with clinical neurologic status. Arch Neurol 1989;46:261-4.

15 Marshall DW, Brey RL, Cahill WT, et al. Spectrum of cerebrospinal fluid findings in various stages of human immunodeficiency virus infection. Arch Neurol 1988;45:954-8.

16 Fischl MA, Richman DD, Crieco MH, et al. The efficacy of azidothymidine (AZT) in the treatment of patients with AIDS and AIDS-related complex: double blind, placebo-controlled trial. N Engl f Med 1987;317:185-91.

17 De Gans J, Lange JMA, Derix MMA, et al. Decline of HIV antigen levels in cerebrospinal fluid during treatment with low-dose zidovudine. AIDS 1988:2:37-40.

18 De Wolf $\mathrm{F}$, Lange JMA, Goudsmit J, et al. Effect of zidovudine on serum human immunodeficiency virus antigen levels in symptom-free subjects. Lancet 1988;ii:373-6.

9 Centers for Disease Control. Classification system for HTLV-III/LAV infections. MMWR 1986;35:334-9.

20 American Psychiatric Association, Committee on Nomenclature and Statistics. Diagnostic and statistical manual of mental disorders. 3rd ed. Washington, DC: APA, 1980.

21 Lange JMA, Paul DA, Huisman HG, et al. Persistent HIV antigenaemia and decline of HIV core antibodies associated with transition to AIDS. Br Med $\mathcal{f}$ 1986;293:1459-62.

22 Dournon E, Matheron S, Rozenbaum W, et al. Effect of zidovudine in 365 consecutive patients with AIDS or AIDS-related complex. Lancet 1988:ii:1297-302.

23 Fauci AS. The human immunodeficiency virus: infectivity and mechanisms of pathogenesis. Science 1988;239:617-22.

24 Navia BA Cho E-S, Petito CK, Price RW The AIDS dementia complex II. Neuropathology. Ann Neurol 1986;19:525-35.

25 Sharer LR, Cho ES, Epstein LG. Multinucleated giant cells and HTLV-III in AIDS-encephalopathy. Hum Pathol 1985;16:760.

26 Wiley CA, Schrier RD, Nelson JA, et al. Cellular localization of human immunodeficiency virus infection within the brains of acquired immunodeficiency syndrome patients. Proc Natl Acad Sci USA 1986;83:7089-93.

27 Ratner L, Polmar SH, Paul N, et al. Cytotoxic factors secreted by cells infected by human immunodeficiency virus type 1. AIDS Res Hum Retroviruses $1987: 3: 147-55$.

28 Lee MR, Ho DD, Gurney ME. Functional interaction and partial homology between human immunodeficiency virus and neuroleukin. Science 1987;237: 1047-51.

29 Tas M, Drexhage HA, Goudsmit J. A monocyte chemotaxis inhibiting factor in serum of HIV infected men shares epitopes with the HIV transmembrane protein gp+1. Clin Exp Immunol 1988;71:13-8.

(Accepted 24 fulv 1989)

\section{ONE HUNDRED YEARS AGO}

Besides the consolidation of the Acts affecting the metropolis promised by Mr. Ritchie, there are now two Bills before Parliament introduced by private members, and concerned more particularly with the housing of the poor. One, prepared by Messrs. Broadhurst, Robert Reid, and Sydney Buxton, proposes to confer on the London County Council power to acquire land, to erect thereon dwellings adapted for the working classes, and to let the same at fair rentals, as well as to provide open spaces, baths, washhouses, etc., in poor districts. The distinguishing feature of the Bill thus far is that, whereas under Lord Cross's and Torrens's Acts the powers of the local sanitary authorities were limited to the condemnation and destruction of unhealthy houses, and to the encouragement of provision of others by private enterprise, or, if, under certain special circumstances, they were permitted to construct, they were bound to relieve themselves of the responsibility within a definite period, they are now enabled to undertake the work themselves, and to assume the position of holders of house property. They are authorised to borrow money for the purposes of the Act, the interest and repayment of which are not to be thrown upon the general rates, but will be provided for by a charge not exceeding one penny in the pound on ground rents, and by a rate to be imposed on vacant land. This last provision, which, whether the framers of the Bill know it or not, they have borrowed from the German law, is not so deserving of adoption as at first sight it might appear; for though it may seem reasonable that the possessor of a house with the luxury of a large garden should pay a higher rate than one of a similar house with only a few square yards of curtilage, it cannot but tend to the closer aggregation of dwellings in suburban districts, a condition already too prevalent. The Bill also provides a cheaper method of compulsory purchase. Another Bill, introduced by Lord Henry Bruce, Major-General Goldsworthy, Sir W. Plowden, and Messrs. Howell and Bazely-White, further amends the Artizans' and Labourers' Dwellings Acts of 1875 to 1885 , and extends to towns throughout the whole country. It also amends those clauses relating to the abatement of nuisances under the Public Health Act, by imposing fines for default, of $£ 10$ for a first offence, $£ 20$ for a second, and $£ 100$ for a third; whereas by the existing law the action of the sanitary authority is restricted to the execution of the necessary improvements and the recovery of the cost from the owner by summary process. It also substitutes obligation for option, on the part of all metropolitan and urban sanitary authorities as regards the adoption of by-laws for the regulation of lodging houses, and enables the Local Government Board to dissolve local "sanitary" authorities that fail to secure the proper sanitary condition of all premises within their respective districts. This is a bold step, but one which past experience of the negligence of these bodies, often largely composed of owners of insanitary property, fully justifies. Lastly, it strikes at the root of much corruption, by reducing to a minimum the claims for compensation for the demolition of unhealthy houses, which, hitherto, calculated on the profits derived by "tenement-mongers" from such property, has actually offered an inducement or premium for extortionate renting of dens totally unfit for human habitation. Differing as these Bills do in their aims and scope, they in no way conflict with one another, and, subject to some amendment in committee, we wish their promoters every success. (British Medical fournal 1889;i:849.) 